\title{
Effects of salmeterol on mucosal inflammation in asthma: a placebo-controlled study
}

\author{
P.K. Jeffery*, P. Venge ${ }^{\#}$, M.J. Gizycki*, I. Egerod ${ }^{\uparrow}$, R. Dahl ${ }^{+}$, P. Faurschou
}

Effects of salmeterol on mucosal inflammation in asthma: a placebo-controlled study. P.K. Jeffery, P. Venge, M.J. Gizycki, I. Egerod, R. Dahl, P. Faurschou. (C)ERS Journals Ltd 2002.

ABSTRACT: Although the anti-inflammatory effects of inhaled corticosteroids in the treatment of asthma are established, the effects of long-acting $\beta_{2}$-adrenergic receptor agonists on inflammation are the subject of debate. The aim of the present study was to determine the effect of salmeterol on the numbers of inflammatory cells in biopsy samples of distinct immunophenotype and those expressing the genes for interleukin-4 and -5 , regulatory cytokines particularly relevant to asthma.

Twenty patients (aged 18-55 yrs) with mild stable asthma were randomised in a three-way crossover study to 6 weeks of treatment with: 1) salmeterol $(50 \mu \mathrm{g} \mathrm{b.d.;}$ SM50); 2) fluticasone propionate (250 $\mu \mathrm{g}$ b.d.; FP250), or 3) placebo.

Compared with placebo, SM50 significantly reduced the numbers of neutrophils in bronchial biopsy samples and the concentrations of myeloperoxidase and soluble E-selectin in serum, each of which reflect neutrophil involvement. Compared with FP250, SM50 reduced neutrophil number and human neutrophil lipocalin level in bronchial lavage fluid and intercellular adhesion molecule-1 level in bronchoalveolar lavage fluid. Compared with placebo, FP250 significantly reduced the numbers of $(\mathrm{CD3}+)$ T-lymphocytes, $(\mathrm{CD} 4+)$ T-helper cells, $(\mathrm{CD} 45 \mathrm{RO}+)$ activated T-helper cells and eosinophils in the biopsy samples; it also reduced the percentage of eosinophils and soluble intercellular adhesion molecule-1 in serum. The percentage of symptom-free days and nights and airways hyperresponsiveness improved significantly after SM50 compared to both placebo and FP250.

In conclusion, a novel antineutrophilic effect of the inhaled long-acting $\beta_{2}$-adrenergic receptor agonist, salmeterol, in mild asthma is reported.

Eur Respir J 2002; 20: 1378-1385.
*Lung Pathology Unit, Dept of Gene Therapy, National Heart and Lung Institute, Imperial College, Royal Brompton Hospital, London, UK. \#Asthma Research Centre, University of Uppsala, Uppsala, Sweden. "University Hospital, Dept of Pulmonary Medicine, Gentofte, Denmark. ${ }^{+}$University Hospital, Dept of Pulmonary Medicine, Aarhus, Denmark.

Correspondence: P.K. Jeffery, Lung Pathology, Royal Brompton Hospital, Sydney Street, London SW3 6NP, UK. Fax: 442073518435

E-mail: p.jeffery@ic.ac.uk

Keywords: Asthma

biopsy

inflammation

neutrophil

salmeterol xinafoate

Received: April 262002

Accepted after revision: July 122002

This study was supported by GlaxoSmithKline Research \& Development Ltd, London, UK.
Asthma is a chronic potentially life-threatening condition that is increasing in both prevalence and severity. In mild-to-moderate asthma, there is persistent bronchial inflammation involving primarily lymphocytic and eosinophilic infiltration associated with remodelling of the airway wall [1, 2]. Activated T-lymphocytes of the T-helper-2 phenotype are generally considered to orchestrate the eosinophilic inflammation via secretion of pro-inflammatory regulatory cytokines that include interleukin (IL)-4 and -5 [3]. Neutrophil numbers are increased in severe asthma, occupational asthma and in association with exacerbations [4-7].

$\beta_{2}$-Selective short-acting $\beta$-agonists are highly effective bronchodilators but there has been some uncertainty as to the effects of their regular use in asthmatics who fail to comply with their prescribed inhaled glucocorticosteroid [8]. Reports have emerged suggesting that short-acting $\beta_{2}$-agonists might even be pro-inflammatory in this group $[8,9]$. However, the introduction of inhaled long-acting $\beta_{2}$-selective agonists, such as salmeterol and formoterol, has shown that, in addition to their relatively long-lasting bronchodilator action, they can also attenuate both the early and late phase responses to experimental allergen challenge, the latter suggestive of anti-inflammatory activity $[10,11]$.

An early study of salmeterol in mild asthma demonstrated no pro-inflammatory effect on either bronchoalveolar lavage (BAL) fluid differential cell counts or inflammatory cell numbers in biopsy samples [12]. A study of formoterol, another long-acting $\beta_{2}$-agonist, in asthmatics, even demonstrated a reduction in the number of biopsy mast cells [13]. Moreover, addition of inhaled salmeterol to the treatment of asthmatics who continued to show symptoms despite current treatment with inhaled corticosteroids resulted in a reduction in airway tissue eosinophil number compared to using an increased dose of inhaled steroid alone [14]. Another study demonstrated that treatment with salmeterol was associated with the increased allergen-induced recruitment of biopsy CD45, CD45RO and mast cells [15]. The results of these studies might appear to be conflicting.

The aim of the present study was to investigate the effects of the long-acting $\beta_{2}$-agonist salmeterol on airway inflammation in mild stable asthma by conducting a placebo-controlled trial to determine 
the numbers of immunohistochemically distinct inflammatory cells and cells expressing the genes encoding IL-2, -4 and -5 and interferon gamma (IFN- $\gamma$ ) in bronchial biopsy samples. As a positive comparator, a corticosteroid arm was included, in which a reduction in the numbers of selected inflammatory cells (i.e. T-helper lymphocytes, eosinophils and mast cells), as reported previously by the present authors and others, was expected. The concentrations of inflammatory mediators in blood and airway lavage fluid were also determined as these are complementary compartments involved in the inflammatory response.

\section{Subjects and methods}

\section{Subjects}

The study received ethical approval from the University Hospital (Gentofte, Denmark) and conformed to the Declaration of Helsinki. All patients gave written informed consent. A total of 20 nonsmoking asthmatic patients receiving treatment with inhaled short-acting $\beta_{2}$-agonist alone were randomised to the study. All subjects were recruited as outpatients from the city of Copenhagen. Of these 20 patients, one withdrew for reasons unrelated to the study. All of the remaining 19 patients (median age 27 yrs (range 20-55 yrs), median forced expiratory volume in one second (FEV1) $74.4 \%$ of the predicted value (range $41-112 \%$ pred), median provocative concentration of methacholine causing a $20 \%$ fall in FEV1 (PC20) $0.15 \mathrm{mg} \cdot \mathrm{mL}^{-1}$ (range $0.3-0.71 \mathrm{mg} \cdot \mathrm{mL}^{-1}$ )) completed the trial and underwent bronchoscopy on three occasions. The characteristics of the subjects are shown in table 1.

Nonsmokers aged $18-55$ yrs with a mean weight of $75 \pm 18 \mathrm{~kg}$ were included. They had to have had a history of asthma, $\geqslant 15 \%$ reversibility in FEV1 (measured 15 min after inhalation of $400 \mu \mathrm{g}$ salbutamol at the first visit) or a documented history of reversibility of $15 \%$ after inhaled $\beta$-agonist within 3 months prior to the start of the study. Bronchial reactivity, as assessed by measurement of $\mathrm{PC}_{20}$, had to be $<4 \mathrm{mg} \cdot \mathrm{mL}^{-1}$. Patients were excluded if they had a respiratory tract infection or asthma exacerbation within 4 weeks of entry into the study and if they had received any asthma medication within the last 2 weeks (apart from inhaled short-acting $\beta_{2}$-agonist). Patients were also excluded if they had received inhaled steroids during the last 2 months or oral steroids during the 3 months prior to the study. Females who were pregnant or lactating were excluded. Patients who were skin-prick test-positive to a seasonal allergen could only take part in the trial if it was outside the season of their allergy.

\section{Study design}

The study was of randomised, placebo-controlled, double-blind, three-way crossover design. There were three 6-week treatment periods, preceded by a 2 -week run-in period and ending with a 2-week follow-up. Each 6-week treatment period directly followed the previous one. After the run-in period, eligible patients were randomised to receive: 1) salmeterol $50 \mu \mathrm{g}$ powder b.d. (SM50); 2) fluticasone propionate $250 \mu \mathrm{g}$ powder b.d. (FP250); or 3) placebo (lactose) powder b.d. via Diskhaler (GlaxoSmithKline, UK). Patients were instructed not to use their regular study medication on the day of the clinic visit. At the first visit, all $\beta$-adrenoreceptor agonists were withdrawn and replaced with salbutamol Rotadisk (GlaxoSmithKline) for use on an "as required" basis for symptomatic relief throughout the run-in and

Table 1. - Characteristics of study subjects

\begin{tabular}{|c|c|c|c|c|c|c|}
\hline Subject & Sex & Age yrs & Smoking history & FEV1 L & FEV $1 \%$ pred & $\mathrm{PC} 20 \mathrm{mg} \cdot \mathrm{mL}^{-1}$ \\
\hline 1 & $\mathrm{~F}$ & 40 & Non & 2.41 & 66.5 & 0.26 \\
\hline 2 & M & 20 & Non & 4.10 & 83.0 & 0.71 \\
\hline 3 & $\mathrm{~F}$ & 35 & Non & 2.58 & 80.5 & 0.18 \\
\hline 4 & $\mathrm{~F}$ & 55 & Non & 1.94 & 77.9 & 0.06 \\
\hline 5 & M & 22 & $\mathrm{Ex}^{\#}$ & 4.36 & 88.4 & 0.17 \\
\hline 6 & $\mathrm{~F}$ & 21 & Non & 2.82 & 77.6 & 0.37 \\
\hline 7 & M & 53 & Non & 2.61 & 64.4 & 0.62 \\
\hline 8 & $\mathrm{~F}$ & 23 & Non & 2.29 & 60.5 & 0.05 \\
\hline 9 & M & 48 & Non & 2.96 & 77.9 & 0.25 \\
\hline 10 & $\mathrm{M}$ & 22 & Non & 6.00 & 112.2 & 0.09 \\
\hline 11 & $\mathrm{~F}$ & 21 & Non & 2.60 & 73.7 & 0.28 \\
\hline 12 & $\mathrm{~F}$ & 25 & Non & 2.83 & 74.4 & 0.03 \\
\hline 13 & M & 40 & Non & 1.80 & 41.2 & 0.05 \\
\hline 14 & $\mathrm{~F}$ & 27 & Non & 2.55 & 65.6 & 0.06 \\
\hline 15 & M & 21 & Non & 3.00 & 62.6 & 0.11 \\
\hline 16 & $\mathrm{~F}$ & 30 & Non & 3.50 & 106.1 & 0.67 \\
\hline 17 & $\mathrm{~F}$ & 30 & Non & 3.13 & 88.4 & 0.14 \\
\hline 18 & $\mathrm{~F}$ & 42 & Non & 2.41 & 67.4 & 0.07 \\
\hline 19 & $\mathrm{~F}$ & 20 & Non & 2.55 & 68.4 & 0.20 \\
\hline Mean & & 31.3 & & 3.00 & 75.6 & 0.29 \\
\hline
\end{tabular}

FEV1: forced expiratory volume in one second; PC20: provocative concentration of methacholine causing a $20 \%$ fall in $\mathrm{FEV}_{1}$; $\%$ pred: percentage of the predicted value; F: female; M: male; Non: nonsmoker; Ex: exsmoker. ${ }^{\#}$ : for 5 yrs. 
treatment periods of the study. During the run-in and treatment periods, patients kept a daily record of their morning and evening peak expiratory flow (PEF), symptoms and rescue salbutamol usage. FEV1 and forced vital capacity (FVC) were recorded at each clinic visit (Vitalograph model S; Spiropharma, Klampenborg, Denmark). Methacholine provocation tests were performed as described previously [16] during the run-in period and once at the end of each of the three treatment periods. Bronchoscopy was performed at the end of each treatment period and at least four endobronchial biopsy samples per bronchoscopic examination were taken unilaterally from second or third order bronchi; previous biopsy sites were avoided. The safety and tolerability of either active or placebo treatments were assessed by monitoring adverse events, blood pressure and the electrocardiogram. Chest radiography was performed at the first visit; all results were normal.

\section{Fibreoptic bronchoscopy}

Diazepam (10 mg orally) was given $1.5 \mathrm{~h}$, atropine $(0.5 \mathrm{mg}$ intramuscularly) $0.5 \mathrm{~h}$ and midazolam (1-5 mg intravenously) immediately before bronchoscopy. The bronchoscopy was performed under local anaesthesia by application of $4 \mathrm{~mL}$ lidocaine gel $\left(40 \mathrm{mg} \cdot \mathrm{mL}^{-1}\right)$ in the chosen nostril. The bronchoscope (BF type 1T20; Olympus, Albertslund, Denmark) was introduced through the nose or mouth, and $3.0 \pm 1.5 \mathrm{~mL}$ lidocaine $\left(40 \mathrm{mg} \cdot \mathrm{mL}^{-1}\right)$ was instilled through the working channel of the bronchoscope over and through the rima glottidis into the trachea. An additional $1.5 \mathrm{~mL}$ was instilled into the trachea and the two main bronchi to avoid cough during bronchoscopy. Biopsy samples were taken using fenestrated spoon forceps. During bronchoscopy, the airways were assessed for visual evidence of inflammation applying a previously validated inflammatory index [17] in which the airways were graded according to the severity of airway oedema, erythema, friability and secretions.

\section{Biopsy samples}

Biopsy samples were fixed immediately on removal from the patient. Two specimens were fixed in freshly prepared $2 \%$ paraformaldehyde in phosphate-buffered saline (PBS; $\mathrm{pH} 7.2$ ) for $2 \mathrm{~h}$ at $4^{\circ} \mathrm{C}$, which was replaced with $15 \%$ sucrose in PBS as cryoprotectant containing $0.01 \%$ sodium azide as preservative, and then snap-frozen and stored at $-80^{\circ} \mathrm{C}$ prior to immunohistochemistical and molecular analyses.

\section{Immunohistochemistry}

Biopsy cryosections were immunostained using commercially available validated antibodies directed against CD45 (catalogue number M701), CD3 (M835), CD4 (M716), CD45RO (M742; all DakoCytomation, Ely, UK), CD25 (20143; Becton Dickinson, Oxford, UK), eosinophil granule (EG)1 and EG2 (both
Pharmacia \& Upjohn Diagnostics, Uppsala, Sweden), mast cell tryptase (Dako M7052), CD68 (Dako M876), neutrophil elastase (Dako M752), IL-4 and -5 (Genzyme Diagnostics, West Malling, UK), and IFN- $\gamma$ (R\&D Systems Europe Ltd, Abingdon, UK). Because of the probable presence of eosinophil-derived endogenous peroxidase, the alkaline phosphatase/antialkaline phosphatase immunostaining method, which reduces background staining, was applied. Nonspecific antibody or PBS was used to replace the primary antibody in negative controls, both of these resulting in minimal background staining. Tonsil tissue and biopsy samples previously obtained for use in other studies were used as positive controls.

In situ hybridisation. The isotopic method of HAMID et al. [18], with which the present authors have previous experience, was used to detect the presence of intracellular messenger ribonucleic acid (mRNA) specific to IL-2, -4 and -5 and IFN- $\gamma$ gene expression. Radioactively labelled antisense (complementary RNA) and sense (mRNA transcripts of the complementary deoxyribonucleic acid of interest) were synthesised in the presence of adenosine triphosphate, guanosine triphosphate, cytidine triphosphate, ${ }^{35} \mathrm{~S}$-uridine triphosphate and SP-6 or T-7 polymerase. The "sense" probe was used as negative control and resulted in minimal staining. Previously validated tissues with confirmed expression of these regulatory cytokines were used as positive controls.

Positively immunostained or radiolabelled cells were counted using an eyepiece graticule in a tissue zone $100 \mu \mathrm{m}$ deep at the external limit of the epithelial reticular basement membrane (referred to as the lamina propria). Adjacent nonoverlapping fields were used for counts until all of the available lamina propria had been analysed. The length of the reticular basement membrane was measured with the aid of an image analysis package, and the results expressed as the number of cells per millimetre of reticular basement membrane.

\section{Bronchial and bronchoalveolar lavage}

Fractional BAL was performed with the bronchoscope wedged in the middle lobe bronchus. Sterile isotonic saline at $37^{\circ} \mathrm{C}$ was sequentially instilled and immediately aspirated (at $80-100 \mathrm{cmH}_{2} \mathrm{O}$ ) as three separate aliquots of $50 \mathrm{~mL}$ each, collected in sterile glass bottles and kept on ice. Bronchial lavage was performed by infusion of $20 \mathrm{~mL}$ saline followed by immediate aspiration and collection in a separate bottle. The aspirated fluid was filtered to remove mucus, the recovered volume measured and the result expressed as a percentage of the infused volume. Aspirated lavage cells were pelleted by centrifugation and the supernatant collected and stored at $-70^{\circ} \mathrm{C}$ until analysis. Total and differential cell counts and the levels of the following inflammatory markers were measured: eosinophilic cationic protein (ECP), eosinophil peroxidase (EPO), eosinophil chemotactic factor, myeloperoxidase (MPO), human neutrophil lipocalin 
(HNL), granulocyte-macrophage colony-stimulating factor, IFN- $\gamma$, IL-2, -4 and -5 , and IL-2 receptor.

\section{Blood}

Blood for biochemical/haematological analysis was taken 2-3 days before bronchoscopy, depending on which day of the week biopsy was performed. This was carried out at the same time as the urine analysis, electrocardiography, chest radiography and measurement of FEV1, FVC and PC20. Venous blood samples for analysis of inflammatory mediator levels were taken $\sim 2 \mathrm{~h}$ before bronchoscopy and before premedication.

Levels of the inflammatory markers, ECP, EPO, HNL and MPO, and soluble adhesion molecules, soluble E-selectin (sE-selectin), soluble intercellular adhesion molecule-1 (sICAM-1) and soluble vascular cell adhesion molecule-1 (sVCAM-1), were measured in serum and plasma. ECP and MPO were measured by radioimmunoassay (Pharmacia Diagnostics, Uppsala, Sweden) according to the manufacturer's instructions. The detection limits of these assays were 2 and $8 \mu \mathrm{g} \cdot \mathrm{L}^{-1}$, respectively. The soluble adhesion molecules were all assayed by enzyme-linked immunosorbent assay (R\&D Systems, Minneapolis, MN, USA) and according to the manufacturer's instructions. The detection limits were $0.1 \mathrm{ng} \cdot \mathrm{L}^{-1}$ for $\mathrm{sE}$ selectin, $0.35 \mathrm{ng} \cdot \mathrm{L}^{-1}$ for sICAM-1 and $2 \mathrm{ng} \cdot \mathrm{L}^{-1}$ for sVCAM-1. EPO and HNL were assayed by radioimmunoassay as described previously, and with detection limits of 0.5 and $3.6 \mu \mathrm{g} \cdot \mathrm{L}^{-1}[19,20]$. The total imprecision of all assays was $<10 \%$ (coefficient of variation).

\section{Statistics}

For the histopathological analysis, all tissue slides were coded prior to examination such that the patient and treatment were unknown to the observer. Based on previously reported power calculations, 20 eligible patients were considered sufficient to provide adequate power for the study [21].

Analyses of variance were applied to the normally distributed data (e.g. measurements of lung function). A nonparametric approach was adopted if $\log$ transformation of the data did not yield a normal distribution (e.g. cell counts) and the analysis proceeded via a series of Wilcoxon rank sum tests for a two-period crossover design adapted for a threeperiod crossover design. For each pairwise comparison, patients were stratified into six groups according to the periods in which the two treatments of interest were administered (irrespective of the order in which the treatments were administered). The groups were paired if the treatments were administered in the same periods and the data analysed within each stratum using the method of КосH [22] for a two-period crossover design. The overall test between two treatments was formed by pooling the three individual Wilcoxon statistics to derive an overall Wilcoxon statistic. All statistical tests were two-tailed and a p-value of $<0.05$ was considered significant.

Each 6-week treatment period directly followed the previous one. The following approach was adopted to test for carryover effects. For each patient, the parameter values for placebo, FP250 and SM50 were summed to give a total value. In the absence of carryover, it would be expected that all patients would have similar total values. The Kruskal-Wallis test was used to determine whether or not these total values were, on average, different between the six sequences in which the different treatments were administered.

\section{Results}

\section{Clinical indices}

There was a significant difference in the number of symptom-free nights and days between SM50 and placebo in favour of SM50 ( $<<0.05$; data not shown). There were no significant differences between the two active and placebo treatments in respect of FEV1, FVC or PEF (morning, evening and diurnal variation). Compared to placebo alone, salmeterol caused a significant improvement in the total inflammatory index (score of 5 reduced to 3; $\mathrm{p}<0.05$ ). FP250 significantly reduced $(p<0.05)$ and salmeterol showed a trend towards reduction $(\mathrm{p}=0.06)$ of the score for erythema (data not shown). Analysis of PC20 demonstrated that SM50 significantly reduced airway hyperresponsiveness compared with placebo and FP250 ( $\mathrm{p}=0.01$ and $\mathrm{p}<0.05$, respectively). Prior to treatment, the geometric mean PC20 was $0.29 \mathrm{mg} \cdot \mathrm{mL}^{-1}$; after 6 weeks of treatment with placebo, SM50 or FP250, the values were $0.44,1.26$ and $0.55 \mathrm{mg} \cdot \mathrm{mL}^{-1}$, respectively.

\section{Biopsy}

The results of the counts of inflammatory cells are shown in table 2. SM50 significantly reduced the numbers of neutrophil elastase-positive cells (i.e. neutrophils) compared to treatment with placebo

Table 2. - Effect of treatment on numbers of inflammatory cells in bronchial biopsy samples

\begin{tabular}{lccc}
\hline & Placebo & SM50 & FP250 \\
\hline Neutrophils & $21.5(0-127)$ & $14.3(0-47)^{*}$ & $18.4(2-120)$ \\
EG1 & $11.8(1-110)$ & $7.0(0-187)$ & $5.5(0-80)^{*}$ \\
EG2 & $8.6(2-197)$ & $6.6(0-139)$ & $4.8(0-40)$ \\
Mast cells & $19.3(0-136)$ & $16.6(0-191)$ & $13.7(0-99)$ \\
CD3 & $77.9(6-206)$ & $52.7(27-140)$ & $56.5(12-105)^{*}$ \\
CD4 & $36.4(5-94)$ & $30.2(2-114)$ & $17.5(3-47)^{* * * *}$ \\
CD45RO & $41.2(3-162)$ & $32.3(9-75)$ & $26.7(3-63)^{*}$ \\
\hline
\end{tabular}

Data are presented as median (range) number of cells per millimetre of reticular basement membrane. Treatment with salmeterol $50 \mu \mathrm{g}$ powder b.d. (SM50) significantly reduced the numbers of neutrophils, whereas fluticasone propionate $250 \mu \mathrm{g}$ powder b.d. (FP250) reduced numbers of eosinophils and lymphocytes compared with the placebo-treated group. EG: eosinophil granule. ${ }^{*}: \mathrm{p}<0.05$ versus placebo; $* *: \mathrm{p}<0.01$ versus SM50. 


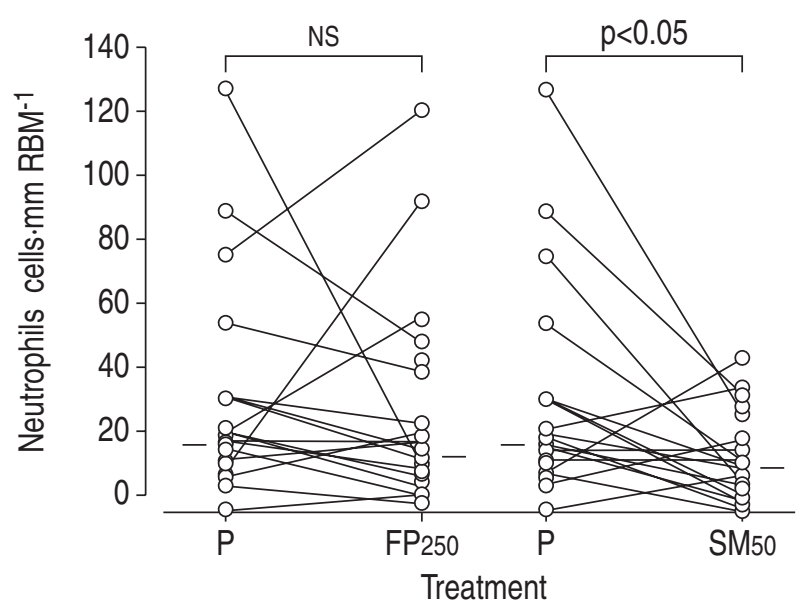

Fig. 1.-Numbers of neutrophils in bronchial biopsy samples. Treatment with salmeterol $50 \mu \mathrm{g}$ powder b.d. (SM50) resulted in a significant decrease in numbers of neutrophils compared with the placebo $(\mathrm{P})$-treated group. The horizontal bars indicate medians. RBM: reticular basement membrane; $\mathrm{FP}_{250}$ : fluticasone propionate $250 \mu \mathrm{g}$ powder $b . d$.

(overall 34\% reduction in median value; fig. 1). Compared to the placebo group, treatment with FP250 significantly reduced the numbers of $\mathrm{CD} 3+, \mathrm{CD} 4+$, CD45RO+ and EG1+ cells by 27, 50, 37 and 50\%, respectively $(\mathrm{p}<0.05$; fig. 2$)$. The numbers of $\mathrm{CD} 4+$ cells were also significantly reduced after FP250 compared with the period in which SM50 was given. The numbers of cells expressing the gene for IL-4 were significantly lower in the SM50 group than in the FP250 group ( $\mathrm{p}<0.05$; fig. 3). There were no significant effects of FP250 on the number of cells expressing the genes for IL-5 or -2 or IFN- $\gamma$.

\section{Lavage}

In the bronchial lavage fluid, the percentage of neutrophils and level of HNL were lower in the SM50 group compared with the FP250 group (neutrophils: 1 (0-89) versus $4(0-74) \%$; HNL: 33.5 (4-286) versus $60.1(11-1437) \mu \mathrm{g} \cdot \mathrm{L}^{-1} ; \mathrm{p}<0.05$ for both) but the SM50 values were not significantly different to those of placebo.

In BAL fluid, the concentration of each of the mediators was low and they were often undetectable. Treatment with SM50 was associated with reduced concentrations of sICAM-1 compared with FP250 (7.8 $(20-110)$ versus $\left.65.6(24-144) \mathrm{ng} \cdot \mathrm{L}^{-1} ; \mathrm{p}<0.05\right)$ and a tendency to lower concentrations of HNL compared with placebo $(\mathrm{p}=0.08)$. In the SM50 group, there was a significant increase in the percentage of CD4+ T-cells compared with placebo (47 (30-82) versus 41 (21-76); $\mathrm{p}<0.01)$. FP250 was associated with a reduction in eosinophil chemotactic factor concentration compared with placebo $(11(1-28)$ versus $19(1-56)$ units $(\mathrm{p}<0.05))$.

\section{Blood}

Compared with placebo, SM50 caused significant reductions in the concentrations of both MPO (fig. 4) and sE-selectin in blood ( $\mathrm{p}<0.05$ for both). FP250, but not SM50, caused a significant reduction in the percentage of blood eosinophils $(p<0.05$; fig. 5). The results of analyses of serum for inflammatory markers of eosinophils (i.e. ECP) and neutrophils (MPO) and relevant soluble adhesion molecules, sICAM-1, sVCAM-1 and sE-selectin, are shown in table 3. FP250 caused a significant reduction in the level of sICAM-1 compared to placebo $(\mathrm{p}=0.01)$. There were no significant differences in the concentrations of EPO or HNL between groups (data not shown).

\section{Carryover effect}

The results of 105 tests for "carryover effect" showed that only two results were significantly different: the numbers of monocytes found in bronchial lavage fluid differential cell counts $(\mathrm{p}=0.02)$ and the number of macrophages in bronchial biopsy samples $(\mathrm{p}=0.05)$. Given that such a large number of such tests at the $\mathrm{p}=0.05$ level would be expected to yield approximately five significantly different results in the absence of true carryover for any of the parameters tested, it was concluded that these were due not to carryover but to chance.

\section{Discussion}

The present study determined the effects of the inhaled long-acting $\beta_{2}$-agonist, salmeterol xinafoate (SM50), on the numbers of immunohistochemically distinct inflammatory cells in the bronchial mucosa of asthmatics and on cells and mediators in blood and bronchial lumina. The effects of SM50 treatment were compared with those of placebo or fluticasone propionate (FP250). As expected, FP250 given over the 6week period significantly reduced numbers of (CD3+) T-lymphocytes, (CD4+) T-helper cells, (CD45RO+) antigen-primed T-cells and (EG1+) eosinophils. These results are in keeping with the already reported effects of inhaled corticosteroids used in the treatment of mild asthma. However, the antineutrophilic effects of SM50 are both novel and interesting, particularly as the asthmatics studied were stable and mild and exhibited relatively low levels of neutrophils and associated markers.

Neutrophil numbers increase in association with the early response to allergen challenge [4], in nocturnal asthma [6], during acute exacerbations [5, 23], and in occupational asthma [24], severe steroid-dependent persistent asthma [7, 25] and sudden fatal asthma [26]. There is also a report of increased neutrophil activation in asthma and a negative correlation of neutrophil numbers and PC20 [27], a finding investigated but not confirmed in the present study. Although inhaled corticosteroids are clearly effective in reducing eosinophil activation and numbers in asthma, they appear to have little effect on neutrophil activation [28]. Indeed, inhaled corticosteroids are reported to increase neutrophil longevity and numbers (in vitro) by inhibition of neutrophil apoptosis [29].

In contrast, the results of the present study 

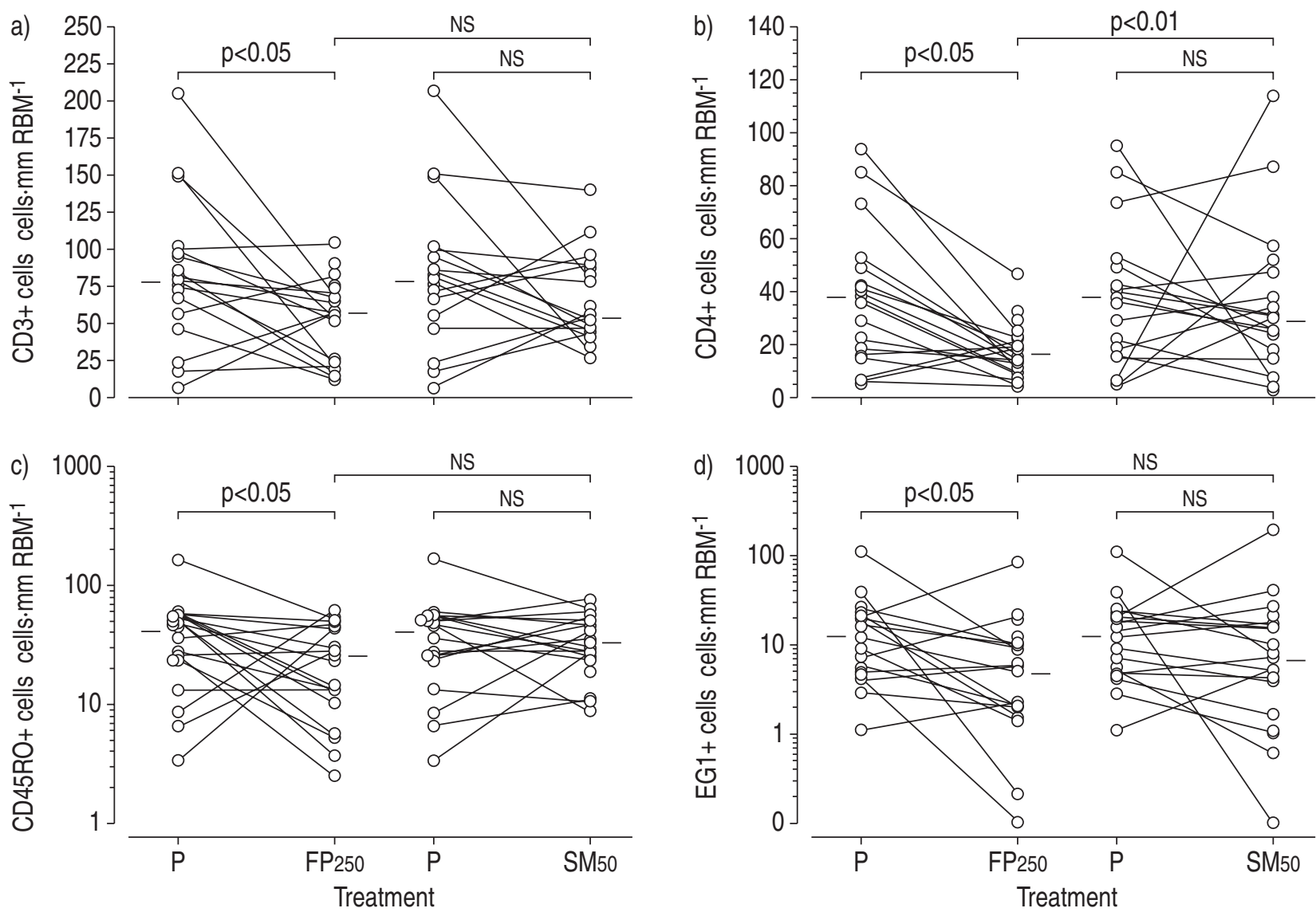

Fig. 2. - Numbers of: a) $\mathrm{CD} 3+$; b) $\mathrm{CD} 4+$; c) CD45RO+; and d) eosinophil granule (EG)1+ cells in bronchial biopsy samples. Treatment with fluticasone propionate $250 \mu \mathrm{g}$ powder b.d. (FP250) resulted in a significant decrease in the numbers of all of these cell types compared with the placebo (P)-treated group. The horizontal bars indicate medians. RBM: reticular basement membrane; SM50: salmeterol $50 \mu \mathrm{g}$ powder b.d.

demonstrate that salmeterol reduces the numbers of tissue neutrophils as well as the concentrations of blood-borne markers and mediators associated with

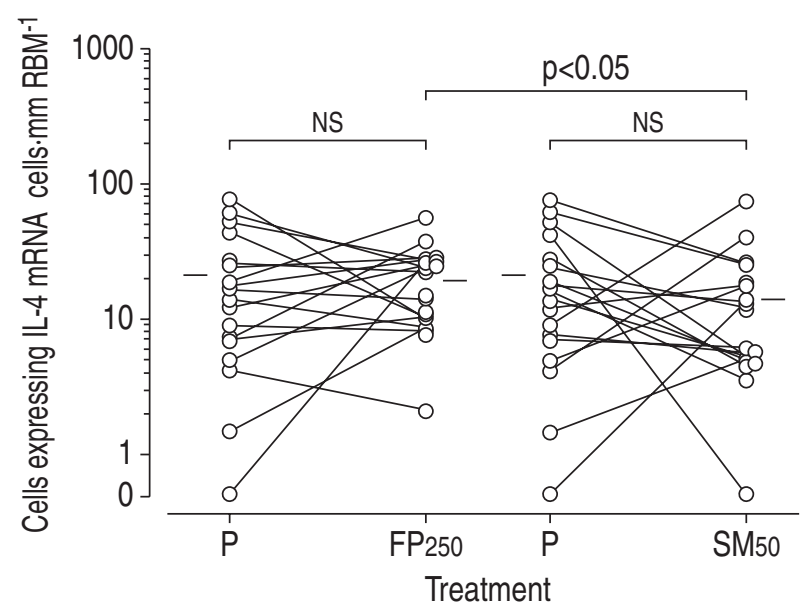

Fig. 3. - Numbers of cells expressing the gene encoding interleukin (IL) -4 in bronchial biopsy samples. Compared with fluticasone propionate $250 \mu \mathrm{g}$ powder b.d. $\left(\mathrm{FP}_{250}\right)$, the number of cells containing IL-4 messenger ribonucleic acid (mRNA) was significantly lower after treatment with salmeterol $50 \mu \mathrm{g}$ powder b.d. (SM50). The horizontal bars indicate medians. RBM: reticular basement membrane; P: placebo. neutrophil recruitment. Salmeterol has also been reported to reduce levels of IL-8, a key neutrophil chemoattractant, in the BAL fluid of asthmatics [30]; this provides one possible mechanism for the observed

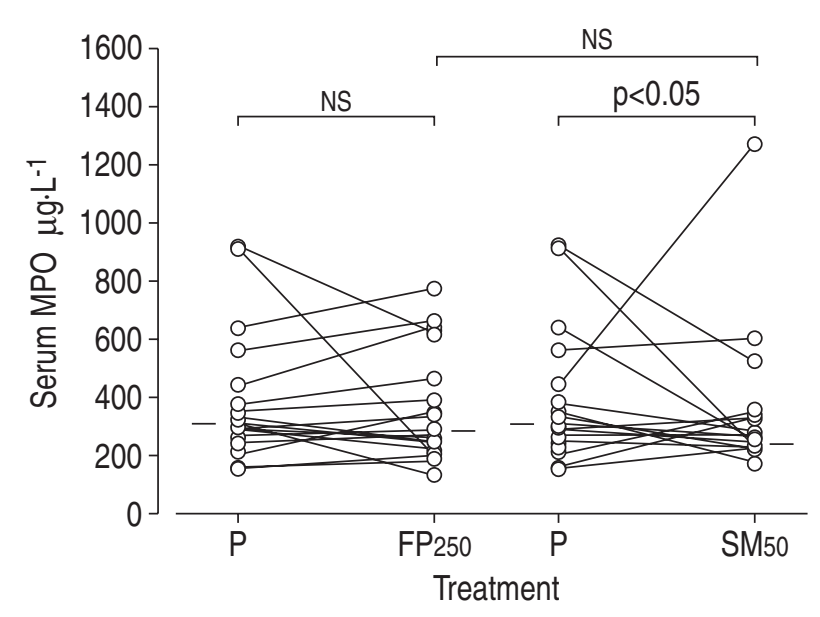

Fig. 4. - Neutrophil myeloperoxidase (MPO) concentration in serum, which reflects the number of neutrophils in blood. Treatment with salmeterol $50 \mu \mathrm{g}$ powder b.d. (SM50) resulted in a significant decrease in MPO concentration compared with placebo (P). The horizontal bars indicate medians. FP250: fluticasone propionate $250 \mu \mathrm{g}$ powder b.d. 


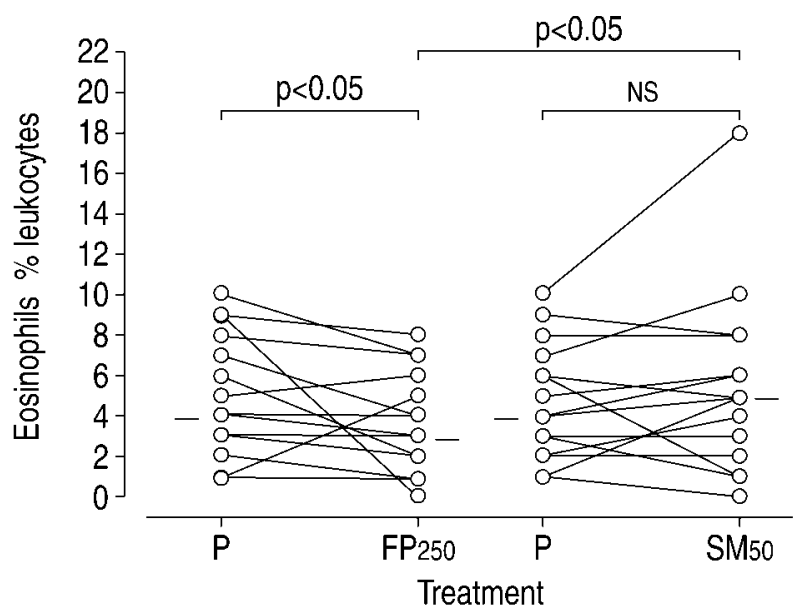

Fig. 5. - Numbers of eosinophils in blood relative to total leucocytes. Treatment with fluticasone propionate $250 \mu \mathrm{g}$ powder $b . d$. $\left(\mathrm{FP}_{250}\right)$ resulted in a significant decrease in the percentage blood eosinophils compared with the placebo $(\mathrm{P})$ or salmeterol $50 \mu \mathrm{g}$ powder b.d. (SM50)-treated groups $(\mathrm{p}<0.05$ for both). The horizontal bars indicate medians.

reduction in neutrophilia in the present study. In vitro and animal experimental studies provide further supportive evidence for the antineutrophilic effects of salmeterol. Salmeterol has been shown to induce apoptosis in neutrophils obtained from asthmatics [31], an effect that would be expected to result in reduced numbers of these cells. Salmeterol has also been shown to inhibit lipopolysaccharide-induced neutrophil accumulation in the lung of experimental animals [32]. Some of these effects are suggested to be due to mechanisms other than its $\beta$-agonist bronchodilator property $[33,34]$.

To the present authors' knowledge, the current report is the first demonstration of a reductive effect of salmeterol on neutrophil numbers in asthma. The

Table 3.-Effects of treatment on concentrations of inflammatory markers in blood

\begin{tabular}{cccc}
\hline & Placebo & SM50 & FP250 \\
\hline $\mathrm{MPO}$ & 302.0 & 249.0 & 286.0 \\
$\mu \mathrm{g} \cdot \mathrm{L}^{-1}$ & $(149-915)$ & $(166-1274)^{*}$ & $(134-759)$ \\
$\mathrm{ECP}$ & 17.2 & 13.7 & 14.1 \\
$\mu \mathrm{g} \cdot \mathrm{L}^{-1}$ & $(6-56)$ & $(7-47)$ & $(4-35)$ \\
$\mathrm{sE}-\mathrm{selectin}$ & 47.4 & 39.5 & 39.1 \\
$\mathrm{ng} \cdot \mathrm{L}^{-1}$ & $(18-147)$ & $(17-93)^{*}$ & $(19-103)$ \\
$\mathrm{sICAM}-1$ & 260 & 261 & 248 \\
$\mathrm{ng} \cdot \mathrm{L}^{-1}$ & $(176-452)$ & $(195-469)$ & $(187-534)^{*}$ \\
$\mathrm{sVCAM}-1$ & 565 & 533 & 518 \\
$\mathrm{ng} \cdot \mathrm{L}^{-1}$ & $(389-681)$ & $(345-766)$ & $(355-798)^{\#}$ \\
\hline
\end{tabular}

Data are presented as median (range). Treatment with salmeterol $50 \mu \mathrm{g}$ powder $b . d$. (SM50) significantly reduced a neutrophil-related marker and relevant adhesion molecule, whereas fluticasone propionate $250 \mu \mathrm{g}$ powder b.d. (FP250) reduced levels of adhesion molecules important to the tissue accumulation of eosinophils. MPO: neutrophil myeloperoxidase; ECP: eosinophil cationic protein; sE-selectin: soluble E-selectin; sICAM-1: soluble intercellular adhesion molecule-1; sVCAM-1: soluble vascular cell adhesion molecule-1. *: $\mathrm{p}<0.05$ versus placebo; ${ }^{\#}: \mathrm{p}<0.05$ versus $\mathrm{SM} 50$. experimental findings and results lead the present authors to speculate that the combination of a corticosteroid and a long-acting $\beta_{2}$-agonist might provide the added benefit of reducing both the eosinophilic and neutrophilic components of the inflammatory response in asthma, particularly the reported increase in neutrophil numbers associated with exacerbations and which develops in severe disease. The clinical benefits of such combination therapy are now accepted and include reduction in exacerbation frequency [35] and severity [36] and improvements in both lung function [37] and symptoms [38].

In conclusion, the present results demonstrate that the long-acting $\beta_{2}$-agonist, salmeterol, shows novel reductive effects on the numbers of neutrophils in mild asthma. The present authors speculate that this antiinflammatory effect of salmeterol could usefully complement the effects of steroids in the treatment of asthma. Additionally, the use of long-acting $\beta_{2^{-}}$ agonists could also be considered for the prevention and treatment of inflammatory and obstructive conditions more often associated with tissue neutrophilia such as chronic obstructive pulmonary disease and cystic fibrosis. Further clinical studies are required to test these hypotheses.

\footnotetext{
Acknowledgements. The authors are indebted to the patients and respiratory nurses, technical staff and secretaries who willingly took part in the present study. They particularly wish to thank D. Li, D. Wang and S. Majumdar (Lung Pathology Unit) for the conscientious and determined application of their expertise in molecular and immunopathology and E. Brodersen and R. Jordal (Central laboratory, Gentofte University Hospital).
}

\section{References}

1. Bousquet J, Jeffery PK, Busse WW, Johnson M, Vignola AM. Asthma. From bronchoconstriction to airways inflammation and remodeling. Am J Respir Crit Care Med 2000; 161: 1720-1745.

2. Jeffery PK. Remodeling in asthma and chronic obstructive lung disease. Am J Respir Crit Care Med 2001; 164: S28-S38.

3. Azzawi M, Bradley B, Jeffery PK, et al. Identification of activated $\mathrm{T}$ lymphocytes and eosinophils in bronchial biopsies in stable atopic asthma. Am Rev Respir Dis 1990; 142: 1407-1413.

4. De Monchy JGR, Kauffman HF, Venge P, et al. Bronchoalveolar eosinophilia during allergen-induced late asthmatic reactions. Am Rev Respir Dis 1985; 131: 373-376.

5. Fahy JV, Kim KW, Liu J, Boushey HA. Prominent neutrophilic inflammation in sputum from subjects with asthma exacerbation. J Allergy Clin Immunol 1995; 95: 843-852.

6. Martin RJ, Cicutto LC, Smith HR, Ballard RD, Szefler SJ. Airways inflammation in nocturnal asthma. Am Rev Respir Dis 1991; 143: 351-357.

7. Wenzel SE, Szefler SJ, Leung DYM, Sloan SI, Rex MD, Martin RJ. Bronchoscopic evaluation of severe asthma. Persistent inflammation associated with high 
dose glucocorticoids. Am J Respir Crit Care Med 1997; 156: 737-743.

8. Sears MR. Short-acting inhaled $\beta$-agonists: to be taken regularly or as needed? Lancet 2000; 355: 1658-1659.

9. Gauvreau GM, Jordana M, Watson RM, Cockcroft DW, O'Byrne PM. Effects of regular inhaled albuterol on allergen-induced late responses and sputum eosinophils in asthmatic subjects. Am J Respir Crit Care Med 1997; 156: 1738-1745.

10. Pedersen B, Dahl R, Larsen BB, Venge P. The effect of salmeterol on the early- and late-phase reaction to bronchial allergen and postchallenge variation in bronchial reactivity, blood eosinophils, serum eosinophil cationic protein, and serum eosinophil protein $\mathrm{X}$. Allergy 1993; 48: 377-382.

11. Dente FL, Bancalari L, Bacci E, et al. Effect of a single dose of salmeterol on the increase in airway eosinophils induced by allergen challenge in asthmatic airways. Thorax 1999; 54: 622-624.

12. Roberts JA, Bradding P, Britten KM, et al. The longacting $\beta_{2}$-agonist salmeterol xinafoate: effects on airway inflammation in asthma. Eur Respir J 1999; 14: 275-282.

13. Wallin A, Sandstrom T, Soderberg M, et al. The effects of regular inhaled formoterol, budesonide, and placebo on mucosal inflammation and clinical indices in mild asthma. Am J Respir Crit Care Med 1999; 159: 79-86.

14. Li X, Ward C, Thien F, et al. An antiinflammatory effect of salmeterol, a long-acting $\beta 2$-agonist, assessed in airway biopsies and bronchoalveolar lavage in asthma. Am J Respir Crit Care Med 1999; 160: 14931499.

15. Boulet LP, Chakir J, Milot J, Boutet M, Laviolette M. Effect of salmeterol on allergen-induced airway inflammation in mild allergic asthma. Clin Exp Allergy 2001; 31: 430-437.

16. Juniper EF, Frith PA, Dunnet C, Cockcroft DW, Hargreave FE. Reproducibility and comparability of responses to inhaled histamine and methacholine. Thorax 1978; 33: 705-710.

17. Thompson AB, Daughton D, Robbins RA, Ghafouri MA, Oehlerking M, Rennard SI. Intraluminal airway inflammation in chronic bronchitis. Characterization and correlation with clinical parameters. Am Rev Respir Dis 1989; 140: 1527-1537.

18. Hamid QA, Corrin B, Dewar A, Hoefler H, Sheppard MN. Expression of gastrin-releasing peptide (human bombesin) gene in large cell undifferentiated carcinoma of the lung. J Pathol 1990; 161: 145-151.

19. Carlson MGC, Peterson CGB, Venge P. Human eosinophil peroxidase: purification and characterisation. J Immunol 1985; 134: 1875-1879.

20. Xu SY, Petersson CG, Carlson M, Venge P. The development of an assay for human neutrophil lipocalin (HNL) to be used as a specific marker of neutrophil activity in vivo and vitro. $J$ Immunol Methods 1994; 171: 245-252.

21. Richmond I, Booth $\mathrm{H}$, Ward C, Walters EH. Intrasubject variability in the airway inflammation in biopsies in mild to moderate stable asthma. Am J Respir Crit Care Med 1996; 153: 899-903.

22. Koch GG. The use of non-parametric methods in the statistical analysis of the two-period change-over design. Biometrics 1972; 28: 577-584.

23. Lamblin C, Gosset P, Tillie-Leblond I, et al. Bronchial neutrophilia in patients with noninfectious status asthmaticus. Am J Respir Crit Care Med 1998; 157: $394-402$.

24. Fabbri LM, Boschetto P, Zocca E, et al. Bronchoalveolar neutrophilia during late asthmatic reactions induced by toluene diisocyanate. Am Rev Respir Dis 1987; 136: $36-42$.

25. Jatakanon A, Uasuf C, Maziak W, Lim S, Chung KF, Barnes PJ. Neutrophilic inflammation in severe persistent asthma. Am J Respir Crit Care Med 1999; 160: $1532-1539$.

26. Sur S, Crotty TB, Kephart GM, et al. Sudden onset fatal asthma: a distinct entity with few eosinophils and relatively more neutrophils in the airway submucosa? Am Rev Respir Dis 1993; 148: 713-719.

27. Kelly C, Ward C, Stenton CS, Bird G, Hendrick DJ, Walters EH. Number and activity of inflammatory cells in bronchoalveolar lavage fluid in asthma and their relation to airway responsiveness. Thorax 1988; 43: 684-692.

28. Schleimer RP, Freeland HS, Peters SP, Brown KE, Derse CP. An assessment of the effects of glucocorticoids on degranulation, chemotaxis, binding to vascular endothelium and formation of leukotriene $\mathrm{B}_{4}$ by purified human neutrophils. J Pharmacol Exp Ther 1989; 250: 598-605.

29. Cox G. Glucocorticoid treatment inhibits apoptosis in human neutrophils. Separation of survival and activation outcomes. J Immunol 1995; 154: 4719-4725.

30. Ward C, Li X, Wang N, et al. Salmeterol reduces BAL IL-8 levels in asthmatics on low dose inhaled corticosteroids. Eur Respir J 1998; 12: Suppl. 28, s380.

31. Lee E, Smith J, Robertson T, Reynolds P, Opesan K, Kilfeather SA. Salmeterol and inhibitors of phosphodiesterase 4 (PDE4) induce apoptosis in neutrophils from asthmatics: $\beta$-adrenergic receptor-mediated salmeterol activity and additive effects with PDE4 inhibitors. Am J Respir Crit Care Med 1999; 159: A329.

32. Whelan CJ, Johnston M, Vardey CJ. Comparison of the anti-inflammatory properties of formoterol, salbutamol and salmeterol in guinea-pig skin and lung. Br J Pharmacol 1993; 110: 613-618.

33. Anderson R, Feldman C, Theron AJ, Ramafi G, Cole PJ, Wilson R. Ani-inflammatory, membranestabilizing interactions of salmeterol with human neutrophils in vitro. Br J Pharmacol 1996; 117: 13871394.

34. Bloemen PG, van den Tweed MC, Henricks PA, et al. Increased cAMP levels in stimulated neutrophils inhibit their adhesion to human bronchial epithelial cells. Am J Physiol 1997; 272: L580-L587.

35. Pauwels RA, Lofdahl C-G, Postma DS, et al. Effect of inhaled formoterol and budesonide on exacerbations of asthma. N Engl J Med 1997; 337: 1405-1411.

36. Tattersfield AE, Postma DS, Barnes PJ, et al. Exacerbations of asthma. Am J Respir Crit Care Med 1999; 160: 594-599.

37. Greening AP, Ind PW, Northfield M, Shaw G and on behalf of Allen \& Hanburys Limited UK Study Group. Added salmeterol versus higher-dose corticosteroid in asthma patients with symptoms on existing inhaled corticosteroid. Lancet 1994; 344: 219-224.

38. Woolcock A, Lund J, Ringler DJ, Jacques M. Comparison of addition of salmeterol to inhaled steroids with doubling of the dose of inhaled steroid. Am J Respir Crit Care Med 1996; 153: 1481-1488. 